\title{
Studies on Chemical Analysis of Goat Milk Basundi with Red Pumpkin Pulp
}

\author{
Wakde Parmeshwar*, Shinde Anant and More Ramprasad \\ Department of AHDS, College of Agriculture,VNMKV, Parbhani- 431402, M.S., India \\ Dept of AHDS, College of Agriculture,Latur, India \\ *Corresponding author
}

\begin{tabular}{l} 
K e y w o r d s \\
$\begin{array}{l}\text { Basundi, red } \\
\text { pumpkin, chemical, } \\
\text { goat milk }\end{array}$ \\
Article Info \\
\hline $\begin{array}{l}\text { Accepted: } \\
\text { 24 August } 2019 \\
\text { Available Online: } \\
\text { 10 September } 2019\end{array}$ \\
\hline \hline
\end{tabular}

A B S T R A C T
In the present study basundi was prepared with Red Pumpkin Pulp. The different levels of red pumpkin pulp 2.5, 5 and 7.5 per cent were tried in goat milk basundi. The requisite samples of basundi with different treatments were subjected for proximate analysis viz. fat, protein, Carbohydrate, moisture, total solid, sucrose and ash. The results obtained were statistically analyzed by using completely randomized design. It was observed that addition of red pumpkin pulp in goat milk basundi decreased (moisture 48.82 to 46.64 per cent, fat 10.64 to 9.80 per cent sucrose 16.89 to 16.20 per cent) and increased (protein 8.15 to 8.64 per cent, ash 1.85 to 2.70 per cent, carbohydrate 30.89 to 32.29 per cent and total solid 51.18 to 53.37 per cent) content significantly in treated $\operatorname{product}\left(\mathrm{T}_{1}, \mathrm{~T}_{2}\right.$ and $\left.\mathrm{T}_{3}\right)$ as compared to control $\left(\mathrm{T}_{0}\right)$.

\section{Introduction}

Goats are important component of livestock industries and play vital role in the social economic structure of economically weak, rural community Goat milk differs from cow or buffalo milk is having better digestibility, alkalinity, buffering capacity and certain therapeutic values in medicines and human nutrition (Haenlein 2004).Due to significant nutritional advantages of goat's milk, it is widely used to feed more starving and malnourished people in the developing world than cow's milk. There is mounting evidence from consumer observations that suggests those who cannot tolerate cow's milk can tolerate goat's milk. An important four year survey of milk drinkers revealed that $66.8 \%$ of those consuming goat's milk did so for medical reasons in particular to overcome intolerance to cow's milk and $27.71 \%$ of those who consumed goat's milk stated that they received significant health benefits from the product(Morgan 2012). The superior digestibility of goat milk, the proper composition of fatty acids and its content of bioactive compounds seem to give properties suitable for treating or preventing certain 
medical conditions. Goat milk also has higher proportions of polyunsaturated fat acid as well as conjugated linoleic acid. Short and medium chain fatty acids, as well as medium chain triacylglycerols have become established medical treatments for several clinical disorders. Goat milk is rich in medium chain triglycerides, which is one of the primary reasons that it facilitates improved nutrient absorption and energy production in the body. (Roy and Vadodaria 2006).

Basundi is traditional, concentrated and sweetened whole milk product having sweetish caramal and pleasant aroma, light to medium brown colour, thick body and creamy consistency with or without soft textured flakes that are uniformly suspended throughout the product. It contains all the solids of milk in an appropriate concentration plus additional sugar and a dry fruit is consumed directly as a delicious sweet dish(Pagote, 2003).

Among the different vegetables red pumpkin (Cucurbita moschata) belongs to family Cucurbitaceae is one of the best-known sources of beta- carotene, a powerful antioxidant that gives orange vegetables and fruits their vibrant colour. Red pumpkin is rich sources of vitamins-A, C, E and $\mathrm{K}$.

It is excellent sources of many polyphenolic flavonoid compounds such as alpha, betacarotenes, cryptoxanthin, lutein and zeaxanthin, carotenes converted into vitamin A inside the human body.

Biologist suggests pumpkins to be highly useful for treating hormonal disorders or adolescent behavior, menopause disorder and intestinal parasite. Hence considering the benefits of fiber in the diet, with respect to its nutritional and medicinal value present study was proposed on "Studies on Preparation of Goat Milk Basundi with Red Pumpkin Pulp."

\section{Treatment combinations}

Following treatment combinations were considered for preparation of basundi with red pumpkin pulp.

$\mathrm{T}_{0}=$ Basundi from goat milk (control)

$\mathrm{T}_{1}=$ Basundi with 2.5 per cent of red pumpkin pulp by weight of goat milk

$\mathrm{T}_{2}=$ Basund $i$ with 5.0 per cent of red pumpkin pulp by weight of goat milk

$\mathrm{T}_{3}=$ Basundi with 7.5 per cent of red pumpkin pulp by weight of goat milk

\section{Physico-chemical analysis of Shrikhand}

Determination of moisture, total solids, ash, sucrose

Determined by method as described in IS: SP (part XI) 1981.

\section{Determination of fat}

Determined by Gerber's method as in IS: 1224 (Part II) (1977).

\section{Determination of protein}

Protein content of basundi was determined byMicrokjeldhal method as described in BIS (1981).

\section{Determination of Carbohydrate}

Carbohydrate content was estimated by subtraction method

\section{Statistical analysis}

The data were analyzed statistically by using Completely Randomized Design (CRD) as per Panse and Sukhatme (1985). 


\section{Results and Discussion}

\section{Mean chemical composition of basundi with different levels of red pumpkin pulp}

The mean chemical composition for control basundi $\left(\mathrm{T}_{0}\right)$ and basundi with 2.5, 5 and 7.5 per cent red pumpkin pulp $\left(\mathrm{T}_{0}, \mathrm{~T}_{1}, \mathrm{~T}_{2}\right.$ and $\left.\mathrm{T}_{3}\right)$ are presented in table 1.

\section{Moisture content of basundi}

Moisture content of $\mathrm{T}_{0}$ (48.82) was significantly higher than the $\mathrm{T}_{1}, \mathrm{~T}_{2}$ and $\mathrm{T}_{3}$. Among the treatments $\left(\mathrm{T}_{1}, \mathrm{~T}_{2}\right.$ and $\left.\mathrm{T}_{3}\right)$ per cent moisture decreased significantly as the level of red pumpkin pulp increased from 2.5 to 7.5 per cent. Significant decrease in moisture content in basundi with red pumpkin pulp could be due to the lower moisture content in red pumpkin pulp (53 gm/100gm). The result was in agreement with Raut et.al(2018)and Lahankaret al., (2018).

\section{Fat content of basundi}

From the result it was observed that the fat content significantly decreased due to addition of different levels $(2.5,5$ and 7.5 per cent) of red pumpkin pulp in basundi. Fat content of control was (10.64per cent) highest among all treatments. Significant decrease in fat content in basundi with red pumpkin pulp could be due to less fat content in red pumpkin pulp (2.3 gm/100gm).The results are in agreement with Bhutkaret al., (2015), Gaikwad et al., and Hajareet al., (2016).

\section{Protein content of basundi}

Protein content of control basundi $\left(\mathrm{T}_{0}\right)$ and basundi with red pumpkin pulp $\left(\mathrm{T}_{1}, \mathrm{~T}_{2}\right.$ and $\left.\mathrm{T}_{3}\right)$ was $8.15,8.31,8.46,8.64$ per cent respectively. The result showed that protein content of control basundi $\left(\mathrm{T}_{0}\right)$ was significantly lower than the basundi with 2.5, 5 and 7.5 per cent addition of red pumpkin pulp and treatment $\mathrm{T}_{3}$ had highest protein (8.64 per cent) content. Among the treatments $T_{3}$ had significantly higher protein content than $\mathrm{T}_{2}$ and $\mathrm{T}_{1}$. This may be due to protein content in red pumpkin pulp $(3 \mathrm{gm} / 100 \mathrm{gm})$. Similar findings were also observed by Kolhe (2003), Matkar (2006).

\section{Ash content of basundi}

The mean ash content in the finished product was 1.85,2.08,2.38,2.70 per cent for $\mathrm{T}_{0}, \mathrm{~T}_{1}, \mathrm{~T}_{2}$ and $\mathrm{T}_{3}$ respectively. From the result it was observed that the ash content of control $\left(\mathrm{T}_{0}\right)(1.85$ per cent) was significantly lower than the $\mathrm{T}_{2}$ and $\mathrm{T}_{3}$.

Among the treatments $\left(\mathrm{T}_{1}, \mathrm{~T}_{2}\right.$ and $\left.\mathrm{T}_{3}\right)$ ash content increased as the level of red pumpkin pulp increased from 2.5 to 7.5 per cent Higher ash content in basundi with red pumpkin pulp could be due to mineral content in red pumpkin pulp $(15 \mathrm{gm} / 100 \mathrm{gm})$. The result is in agreement with Waghmare (2012), Gaikwad et al., (2016) and Kapare (2017).

\section{Carbohydrate content of basundi}

It was observed that the carbohydrate content was increased significantly due to addition of different levels $(2.5,5$ and 7.5 per cent) of red pumpkin pulp in basundi.

However, the carbohydrate content of $\mathrm{T}_{3}$ (32.29 per cent) was significantly higher than the control $\left(\mathrm{T}_{0}\right)$ as well as treatment $\mathrm{T}_{1}$.

Significant increase in carbohydrate content of basundi at higher level of addition of red pumpkin pulp could be due to carbohydrate content in red pumpkin pulp $(66.6 \mathrm{gm} / 100 \mathrm{gm})$. The result is in agreement with previous research workers, Bankar (2011), Navale et al., (2014). 


\section{Experimental Methodology}

Fig.1 Flow diagram for preparation of Basundi with Red Pumpkin Pulp.

Basundi was prepared as per the method of Mukhekar, (2014).

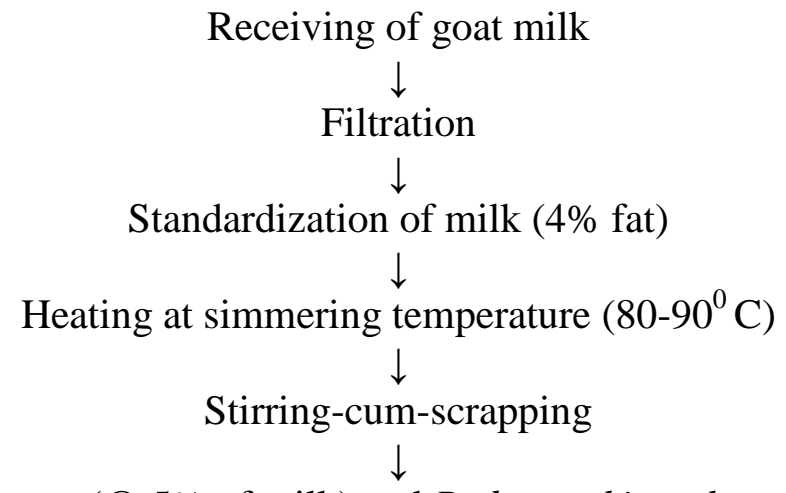

Addition of sugar (@ 5\% of milk) and Red pumpkin pulp as per treatment

Gentle heating till complete sugar dissolved and uniform mixing of Red Pumpkin Pulp

Cooling at room temperature and addition of cardamom (1/2 tbsp)

Packaging and storage of basundi at refrigeration temperature

Table.1Mean chemical composition of basundi with different levels of redpumpkinpulp

\begin{tabular}{|l|l|l|l|l|l|}
\hline $\begin{array}{l}\text { Sr. } \\
\text { No. }\end{array}$ & $\begin{array}{l}\text { Chemical } \\
\text { constituents }\end{array}$ & $\mathbf{T}_{\mathbf{0}}$ & $\mathbf{T}_{\mathbf{1}}$ & $\mathbf{T}_{\mathbf{2}}$ & $\mathbf{T}_{\mathbf{3}}$ \\
\hline $\mathbf{1}$ & Moisture (\%) & $48.82^{\mathrm{a}}$ & $47.94^{\mathrm{b}}$ & $47.17^{\mathrm{c}}$ & $46.64^{\mathrm{cd}}$ \\
\hline $\mathbf{2}$ & Fat (\%) & $10.64^{\mathrm{a}}$ & $10.30^{\mathrm{b}}$ & $10.00^{\mathrm{c}}$ & $9.80^{\mathrm{d}}$ \\
\hline $\mathbf{3}$ & Protein (\%) & $8.15^{\mathrm{c}}$ & $8.31^{\mathrm{bc}}$ & $8.46^{\mathrm{b}}$ & $8.64^{\mathrm{a}}$ \\
\hline $\mathbf{4}$ & Ash (\%) & $1.85^{\mathrm{d}}$ & $2.08^{\mathrm{c}}$ & $2.38^{\mathrm{b}}$ & $2.70^{\mathrm{a}}$ \\
\hline $\mathbf{5}$ & Carbohydrate(\%) & $30.89^{\mathrm{d}}$ & $31.78^{\mathrm{c}}$ & $31.99^{\mathrm{b}}$ & $32.29^{\mathrm{a}}$ \\
\hline $\mathbf{6}$ & Total solids $(\%)$ & $51.18^{\mathrm{d}}$ & $52.06^{\mathrm{c}}$ & $52.83^{\mathrm{b}}$ & $53.37^{\mathrm{a}}$ \\
\hline $\mathbf{7}$ & Sucrose $(\%)$ & $16.89^{\mathrm{a}}$ & $16.53^{\mathrm{b}}$ & $16.31^{\mathrm{bc}}$ & $16.20^{\text {cd }}$ \\
\hline
\end{tabular}




\section{Total solids content of basundi}

Total solid content of control basundi $\left(\mathrm{T}_{0}\right)$ was significantly lower (51.18) than the basundi with red pumpkin pulp $\mathrm{T}_{1}, \mathrm{~T}_{2}$ and $\mathrm{T}_{3}$ (52.06, 52.83, 52.37 per cent respectively).Moisture content directly influenced the total solid percentage; decrease in moisture content of product increases the total solid content. The highest total solid content was recorded in treatment $\mathrm{T}_{3}$ (53.37 per cent) and lowest total solid content was recorded for treatment $\mathrm{T}_{0}$ (51.18 per cent). However, among the treatments total solid content increased significantly as per cent level of red pumpkin pulp increase from 2.5 to 7.5 per cent. Increase in total solid content in treated product could be due to lower moisture content in red pumpkin pulp. The results are in agreement with Pawar (2011).

\section{Sucrose content of basundi}

It was observed that the sucrose content in control $\left(\mathrm{T}_{0}\right)$ and treatment $\mathrm{T}_{1}, \mathrm{~T}_{2}$ and $\mathrm{T}_{3}$ was $16.89,16.53,16.31,16.20$ per cent respectively. Among the treatment's sucrose content of $\mathrm{T}_{0}(16.89)$ was highest where as $\mathrm{T}_{3}(16.20)$.

From present investigation it can be concluded that the red pumpkin can be very well utilized for preparation of palatable, nutritional basundi. From the results of chemical analysis of goat milk basundi with addition of red pumpkin pulp (2.5, 5 and 7.5 per cent) it could be concluded that red pumpkin pulp could be incorporated up to 7.5 per cent in basundi without affecting sensory properties adversely.

Addition of red pumpkin pulp in basundidecreased moisture, fat, and sucrose content significantly in the finished product as compare to control. Protein, ash, carbohydrate and total solid content was increased significantly in treated product as compared to control.

\section{References}

Bankar, S.N. 2011. Studies on Preparation of Pineapple Burfi. M.Sc.(Agri.) Thesis submitted to MKV, Parbhani.

Bhutkar, S S., Patil, D.L., and Rupanawar, D.A. 2015. Studies on Preparation of Pedha Blended with Red Pumpkin. IOSR. J. of Agriculture and Veterinary ScienceVolume 8, Issue 3 Ver. I (Mar. 2015), PP : 01-03.

Haenlein, G.F.W.2004. Goat milk in human nutrition. Small Ruminant Research, 51: 155-163.

Gaikwad, A.S., Chavan, K.D., and More, K.D. 2016. Preparation of Fibre Fortified Basundi Using Date Fruit (Phoenix dactylifera) J. ofNutrition and Health Sciences Volume 3 ISSN: 2393 - 9060.

Hajare, V.H. 2011. Studies on preparation of Almond Burfi.M.Sc. (Agri.) Thesis Submitted to MKV, Parbhani.

IS: SP: 18 Part XI. 1981. Methods of test for dairy industry. Rapid examination of milk. Indian Standard Institution, Manak Bhavan, New Delhi.

ISI 1977. IS: 1224 (Part II) Determination of Fat by Gerber's Method. Indian Standard Institution, Manak Bhavan, New Delhi.

Kapare, P.B. 2017. Studies on Preparation of Burfi Blended with Finger Millet. M. $\mathrm{Sc}$ (Agri) Thesis Submitted to VNMKV Parbhani.

Kolhe, P.Y. 2003. Utilization of Papaya Pulp in Preparation of Burfi. M.Sc. (Agri.) Thesis submitted to Dr. PDKV, Akola. (MS).

Lahankar, S.V., Narwade, S.G., and Kamble, N.S. 2018. Preparation of Burfi Blended with Green Peas.Int. J. Curr. Microbiol. App. Sci (2018) Special Issue-6: 2320-2325

Matkar, S.P. 2006. Preparation of Fig Burfi. M.Sc. (Agri.) Thesis submitted to MKV, Parbhani 
Morgan D, Gunneberg C, Gunnell D, Healing TD, Lamerton S.2012.Medicinal properties of goat milk. J Dairy Goat 90: 1.

Mukhekar, A.S. 2014. Preparation of Basundi Blended with Mango Pulp cv. Kesar. M.Sc (Agri.) Thesis, Submitted to VNMKV, Parbhani.

Navale, A.S., Deshmukh, B.R., Narwade, S.G., Korake, R.L., and Mule, P.R. 2014. Production profile proximate composition, sensory Evalution and Cost Configuration of Wood Apple Burfi. Animal Science Reporter. 8 (3): $114-120$

Pagote, C.N. 2003. Basundi: A Traditional Delicious Milk Product. Beverage and Food World, 30(6): 29.

Panse, V.G., and Sukhatme, P.V. 1985.
Statistical Methods for Agricultural Workers. ICAR

Publication, New Delhi.

Pawar, S.B. 2011. Studies on preparation of burfi blended with dried date. M.Sc. (Agri) Thesis submitted to MKV, Parbhani.

Raut, M. M. 2018. Studies on preparation of buffalo milk basundi with red pumpkin pulp. M.Sc.(Agri.) Thesis submitted to VNMKV, Parbhani.

Roy, S.K, and Vadodaria, V.P. 2006. Goat Milk and Its Importance. Indian Dairyman 58: 65-9.

Waghmare, V.K. 2012. studies on preparation of bottle gourd burfi. M.Sc. (Agri.) Thesis Submitted to MKV, Parbhani (MS).

\section{How to cite this article:}

Wakde Parmeshwar, Shinde Anant and More Ramprasad 2019. Studies on Chemical Analysis of Goat Milk Basundi with Red Pumpkin Pulp. Int.J.Curr.Microbiol.App.Sci. 8(09): 28472852.doi: https://doi.org/10.20546/ijcmas.2019.809.326 